\title{
Another nexus? Exploring narratives on the linkage between EU external migration policies and the democratization of the southern Mediterranean neighbourhood
}

Luisa Faustini-Torres ${ }^{1,2}$ (i)

Correspondence: Luisa.faustini@upf. edu

${ }^{1}$ University Pompeu Fabra, Jaume I Building, Ramon Trias Fargas 25-27, 08005 Barcelona, Spain

${ }^{2}$ GRITIM-UPF, Barcelona, Spain

\begin{abstract}
Since the beginning of the twenty-first century and after two turning point events 09-11 terrorist attacks and the 'Arab spring' - both migration control and democracy promotion became central issues within EU foreign policy, in particular to what concern its relations with the southern Mediterranean neighbourhood. However, although many authors allude to the relation between these two policy dimensions, little is known about their linkage. On the one hand, the debate about EU external migration policies narratives has revolved mainly around the migration-security and migration-development nexus. On the other, whereas the developmental paradigm has dominated the root-causes approach little attention has been given to its political dimension. This article aims to overcome these limitations through exploring these other nexus: the one between these policies and the democratization of southern Mediterranean countries. To investigate this nexus I follow a Narrative Policy Analysis approach - the most suitable for investigating issues of high complexity, uncertainty and polarization, which seems to be precisely the case of EU external migration policies. Hence, drawing on longitudinal and interpretative content analysis of EU official documents covering the period between 1995 and 2018, this study seeks to expose the main narratives casted by the EU on the issue and to identify if there has been consistence or change in the stories and arguments over time and in particular, before and after the 'Arab spring'. Ultimately, the goal was to confirm the presence of this nexus by exposing its complexity and trying to understand its configuration. This is considered as an important step towards further disentangling the logics and impacts of the externalization of EU migration policies towards its Southern Mediterranean neighbourhood.
\end{abstract}

Keywords: EU external migration policies, Southern Mediterranean neighbourhood, Democratization, Narrative policy analysis

\section{Introduction}

With the end of the Cold War and especially after 09/11 terrorist attacks, democratization became a major topic within the foreign policy discourse in Western countries. As a result, democracy promotion and other related values, such as good governance and human rights, became a key priority of Western governments and a central issue framing its external relations, as it is the case of the European Union

(c) The Author(s). 2020 Open Access This article is distributed under the terms of the Creative Commons Attribution 4.0 International License (http://creativecommons.org/licenses/by/4.0/), which permits unrestricted use, distribution, and reproduction in any medium, provided you give appropriate credit to the original author(s) and the source, provide a link to the Creative Commons license, and indicate if changes were made. 
[EU]. Already in 1992, the EU introduced 'respect for human rights and democracy' as an essential element clause of its relations with third countries. Moreover, there is a broad agreement in the literature that the EU presents itself to the world as a normative and benevolent actor promoting democratic principles worldwide (Manners, 2002). Likewise, since Tampere Council in 1999 and through a process broadly referred by the literature as 'externalization', ${ }^{1}$ migration control progressively became an essential feature of EU foreign policy. In fact, during the past two decades, the development of the external dimension of EU migration policies was consolidated as the main strategy for dealing with migration flows from the Global South. ${ }^{2}$

This becomes even more evident when considering the specific context of EU relations with countries in the Southern Mediterranean neighbourhood ${ }^{3}$ (i.e. Morocco, Algeria, Tunisia, Egypt and Libya). This region has been, simultaneously, a priority for EU external migration policies (Commission, 2012) and a target of democracy promotion efforts (Cassarino, 2012; Pace, 2014). The advent of the 'Arab spring' in 2011 and the 'migration crisis' in 2015-16 made this region even more complex, especially with regard to the interaction between externalization strategies and democratization. However, despite being essential components of EU's external action and central elements of EU relations with the neighbourhood, little is known about how these two policy dimensions intertwine within EU official narratives.

It has been suggested that when the external dimension of EU migration policies was first designed, back in 1999, it was regarded as a comprehensive approach, guided by two overarching narratives: the 'remote-control' or 'securitized' approach and the 'rootcauses' or 'preventive' approach ${ }^{4}$ (Boswell, 2003; Yildiz, 2016; Zapata-Barrero, 2013). In the first one, migration is framed through security discourses, whereas in the second it holds a strong developmental discourse on its core (Fratzke \& Salant, 2018). As a result, the academic debate about EU narratives behind these policies has revolved mainly around the axis migration-development (van Hear \& Sørensen-Nyberg, 2002) and migration-security nexus (Pinyol-Gimenez, 2012) as well as the tensions inherent to their prioritization and articulation.

Even though democratization appears to be an important pillar of EU external migration policies under the 'root-causes' approach, the debate about the migrationdemocratization nexus in this context has been either side-lined by the security discourse or subsumed into the developmental debate. Moreover, it is not surprising to observe that the migration-development nexus, and in particular what concerns economic aspects of development, such as poverty and unemployment, has been the dominant paradigm within the 'root-causes' approach. This could be related to the tendency of reducing migration to an economic act (van Hear \& Sørensen-Nyberg, 2002). As a

\footnotetext{
${ }^{1}$ Other terms have also been used to refer to this process such as 'external dimension' (Boswell, 2003), 'external governance' (Lavenex, 2006) and 'extra-territorialisation' (Rijpma \& Cremona, 2007).

${ }^{2}$ This term refers to the countries that are mostly, although not necessarily, located in the Southern Hemisphere. Here this term is used meaning the countries classified as belonging to the "underdeveloped", "developing", "dependent" world.

${ }^{3}$ Although the region also includes Lebanon, Syria, Jordan, Palestine and Israel, here I will not be considering these countries since they are influenced by regional dynamics that would bring unnecessary complexities to the analysis, such as the conflict in Syria and that between Palestine and Israel.

${ }^{4}$ Apart from these two, the literature also underlined the existence of a third, although less applied, approach: the 'managerial approach' (see Aubarell, Zapata-Barrero, \& Aragall, 2009).
} 
consequence, more political 'root-causes', such as democratization and human rights promotion have not received as much attention.

In this article, I argue that it is necessary to go beyond this dichotomy and explore another nexus that is still under-researched: the one between EU external migration policies and the democratization of the southern Mediterranean neighbourhood. This is mainly because despite being a compilation of many policy narratives, it seems that not all stories behind these policies have been equally acknowledged or understood. Thus, this research presents itself as an attempt to start fulfilling these gaps, something that could be considered as crucial step for further disentanglement of the logics and consequences of the externalization of EU migration towards this region.

The article has been divided as it follows. I begin by introducing the Narrative Policy Analysis [NPA] approach, the main framework applied for exploring this nexus. At this point, I justify the reasons for following this approach and its adequacy for delving into this policy field. The goals, methods and data sources behind the analysis are also explained. In the following section, I present the main findings by describing the different narratives identified and the nexus configuration embedded in it. Particular emphasis is given to the different arguments and stories encountered throughout time and among EU institutional bodies. Finally, in the conclusion, I discuss the implications of this nexus for the broader debate of EU external migration policies, raising hypothesis and indicating future research lines based on the first mapping presented here.

\section{The narrative policy analysis approach}

To investigate how EU external migration policies and democratization intermesh in the context of EU-Mediterranean relations, I chose to follow a theoretical approach that sets narratives in the centre of the policy process, applying mainly the NPA approach provided by Roe (1994). This choice was motivated by three main rationalities.

Firstly, an important premise in this research is that policymaking is not linear (Sabatier, 2006). This implies that EU external migration policies are conceived here as a messy and complex policy process (Guiraudon, 2003), ${ }^{5}$ that is, as part of ongoing processes of negotiation between multiple actors over time (Roe, 1994), which hold different values, perceptions and policy interests (Sabatier, 2006), and whose interactions are constrained by power relations (Brock, Cornwall, \& Gaventa, 2001). To investigate this sort of policy processes, one needs to address questions such as thow problems and solutions are defined, by whom and with what effects' (Keeley \& Scoones, 2003; Wolmer, 2006).

With the argumentative turn in the field of policy analysis, the literature that uses policy frame as a key analytical tool to answer these questions gained increased relevance (Brock et al., 2001). Since then, researchers started to pay special attention to "the ways in which particular concepts or story-lines 'frame' what and who is taken into consideration in and excluded from policy deliberation" (Brock et al., 2001, p. 5). Rather than being perceived as a random act, policy framing is conceived as the conscious and intentional selection of language and meaning to influence political debate

\footnotetext{
${ }^{5}$ Guiraudon (2003) exposed in a seminal article the power competition among diverse actors in the development of the EU immigration and asylum policy by applying the 'garbage can model', indicating that the process would be more complex than the simple interaction between high-level decision makers would suggest.
} 
and decision-making (Bacchi, 2009). In this sense, the importance of different practices of policy framing and styles of storytelling for policy process analysis should not be underestimated (Wolmer, 2006).

The NPA approach focus on one particular type of story, which are policy narratives (Kaplan 1986; Roe 1991, 1994). On the one hand, "narratives are the lifeblood of politics" (McBeth, Shanahan, Arnell, \& Hathaway, 2007, p.88), playing significant roles within the policy process and being essential for understanding policy issues and their configuration. On the other, narratives are also simplified and programmatic tales of cause and effect, which provide a diagnosis of the problem as well as definition of its solutions (Wolmer, 2006). This makes them predictable and testable sources of study, that is, "written words that can be easily documented and tracked through a temporal perspective" (Sabatier and Jenkings-Smith, 1993, p.16 quoted by McBeth et al., 2007). Thus, looking into narratives allows digging into the policy process of EU external migration policies in a structured manner without neglecting its complex nature.

The second reason for choosing the NPA is the fact that it "requires uncertainty, complexity and polarization as a continuing precondition for analysis" (Roe, 1994, p. 17). Uncertainty means lack of knowledge about what matters and how things are related. Many researchers agree that migration policies are usually characterized by a high degree of uncertainty towards the dynamics, root-causes (Gent, 2002) and effects of migration (Boswell, Geddes, \& Scholten, 2011). Complexity refers to the internal intricacy contained in the issue and its interdependence to other policy issues. This also seems to be the case of migration policies, mainly because it is interconnected to several other issues, such as development, trade, security, conflict etc. This can be further confirmed by the debates and concerns related to external policy coherence, which refers to the complex nature of international migration and its sensitivity to interactions with other policy areas (Wunderlich, 2013).

There are reasons to believe that this case might also involve a certain degree of polarization, which denotes the concentration of groups around the extremes of the policy issues (Roe, 1994). Authors have underlined the fact that when 'going abroad' with its migration policies and instruments, the EU is not a monolithic actor (Geddes \& Lixi, 2018); contradicting the idea that policymaking at this level occurs without controversies and ambiguities. In fact, EU different institutional bodies would often have different understandings of migration and its challenges, thereby developing their actions based on different priorities (Ibid).

The Commission has been one of the leading actors behind the formulation and implementation of EU external migration policies. Within this institutional body, the Directorate-General Migration and Home Affairs (DG HOME) has been at the driver's seat of the EU external migration policy (Carrera, Radescu, \& Reslow, 2016, p. 45). This is important because, the DG HOME tends to give higher priority to migration control and security in comparison to other DGs such as DG International Cooperation and Development (Carrera, et al., 2016). Another important actor, the Council - led mainly by Justice and Home Affairs officials - also tends to adopt a security-driven approach to migration (Carrera, et al., 2016). Unlike the previously mentioned, the Parliament has been, since the beginning, critical to the focus on security and control and to the inconsistency between addressing root-causes and curbing migration (Carrera, et al., 2016). However, despite the changes introduced by the Treaty of Lisbon in 2009, authors underline that the role played by this institutional body is still limited and ad hoc (Carrera, den Hertog, \& Parkin, 2013). 
The final reason for using NPA as the main theoretical framework is related to the gap between rhetorical commitment and practice, that is, between policy intentions embedded in the policy narratives and its outcomes. However, the fact that narratives might remain at the rhetorical level does not imply that they are less important or insignificant. In fact, they may actually play many roles - such as instrumental (Roe, 1994) and legitimizing (Vega, 2017) roles - and produce real material consequences (Cornwall \& Brock, 2005). Most importantly, understanding narrative political strategies would be essential for studying policy change in a complex environment (McBeth et al., 2007, p. 104). Primary policy beliefs tend to be much more stable over time despite their representational inaccuracy and/or the existence of contradictory evidence (Roe, 1994). On the contrary, narrative political strategies are much more dynamic (McBeth et al., 2007). Consequently, both change and consistence should be considered as an object of enquire.

\section{Goals and methods of analysis}

Strictly speaking, the NPA consists of four consecutive steps. ${ }^{6}$ However, in this article the empirical analysis has been restricted to the first two, which focus on (1) the identification of narratives that are dominant in the issue and (2) the identification of other narratives that either "do not conform to the definition of story (non-stories) or that run counter to the controversy's dominant policy narratives (counter-stories)" (Roe, 1994, p. 3). A further aim was to investigate if there has been consistence or change in the stories and arguments over time and among different actors.

\section{Data sources}

The analysis was based on longitudinal and interpretative content analysis of key official documents shaping EU external migration policies and Euro-Mediterranean relations. Documents were selected following two logics (see Additional file 1: Annex I for a complete list). The first one consisted in choosing the documents indicated by the literature and the EU itself as being the key ones shaping EU external migration policies and relations with the Southern Mediterranean neighbourhood. The second one derived from the process of inter-textual reading.

The timeframe considered ranges from 1995 to 2018. The Euro-Mediterranean Partnership, launched through the Barcelona Process in 1995, was chosen as the starting point since it marked not only the institutionalization of EU-Mediterranean relations but also EU compromise with the advancement of human rights and democracy in the region (Fernández-Molina, 2018). Moreover, it was when the EU declared its intentions of creating an area of security, peace and stability and shared prosperity in the neighbourhood for the first time (Barcelona Declaration, 1995), particularly attaching democratization and migration control to the advancement of these goals.

For the diachronic comparison, one main time marker was considered: the year 2011 and the so-called 'Arab spring'. These events have been selected because they configured an unprecedented moment in relation to processes of democratization and political change in the southern Mediterranean, raising many questions concerning the involvement of the EU and its member states in the region. In this sense, the 'Arab

${ }^{6}(1)$ Definition and identification of stories and narratives (2) Identification of other narratives: non-stories and counter-stories (3) Comparison and generation of meta-narrative and (4) Creation of new policy narrative. 
spring' would fit into the definition of policy spaces, which are "moments in which interventions or events throw up new opportunities, reconfiguring relationships between actors within these spaces or bringing in new actors and opening up the possibilities of a shift in direction" (Grindle and Thomas 1991 quoted by Brock et al., 2001, p. 22). Additionally, although most of the literature indicates continuity of policies before and after the uprisings (Teti, 2012), here I follow the idea that this continuity should not be taken for granted and that research should pay attention to specific policy fields as well as more subtle changes within the narratives (Roccu \& Voltolin, 2018). However, two other key moments have also being kept in mind for the analysis: the 'cayucos crisis' in 2005 and the 'migration crisis' in 2015-16.

Documents were classified considering the year they were issued and the main EU institutional body involved in their production (see Fig. 1). This classification allowed for the crosstabbing of coded fragments, which was essential for having a clear idea of the origin and sequence of statements and the comparison of narratives across time and among actors.

\section{Data coding and analysis}

The main unit of analysis were policy narratives. According to Roe (1994, pp. 34-35), narratives might appear in the format of a classic story, with beginning, middle, and end, or in the format of an argument, with premises and conclusions. In order to identify and compare the most relevant stories and/or arguments, I used the software for Qualitative Data Analysis Nvivo, where all the collected data (official documents) were uploaded, classified, coded and analysed.

Data was coded combining both deductive and inductive approaches. I started identifying the 'meaning units' (fragments of data of one or more paragraphs in which meaning is found or constructed) using a first list of codes (labels) based on concepts extracted from the NPA (theory-led deductive approach). In this sense, the main structure searched within the data were 'problem statements', which consisted of the main parental node from which all others would derive (see Fig. 2). Usually, a 'problem statement' would contain the definition of the problem (diagnosis) and the proposed solution (treatment), asserting a causal(s) relationship(s) between $\mathrm{X}$ and $\mathrm{Y}$. Other related elements have also been coded: (a) assumptions and premises and (b) scenarios ('prognosis') (see Fig. 3). Both are considered to have an influence in the configuration of the problem diagnosis and treatment.

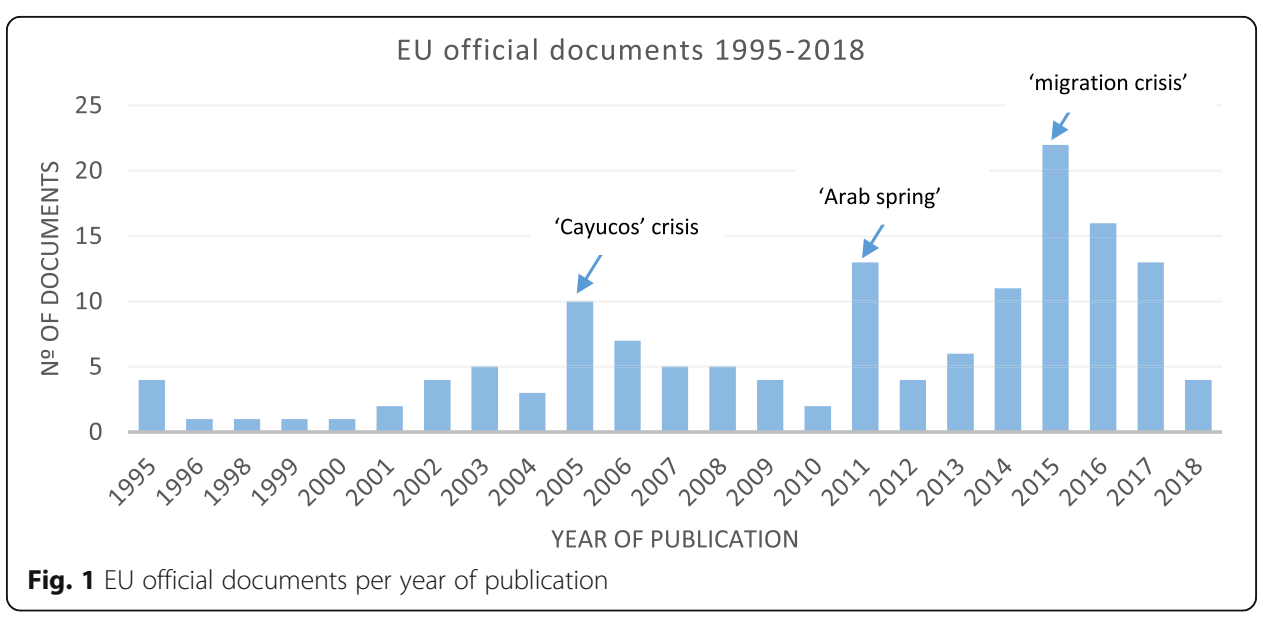




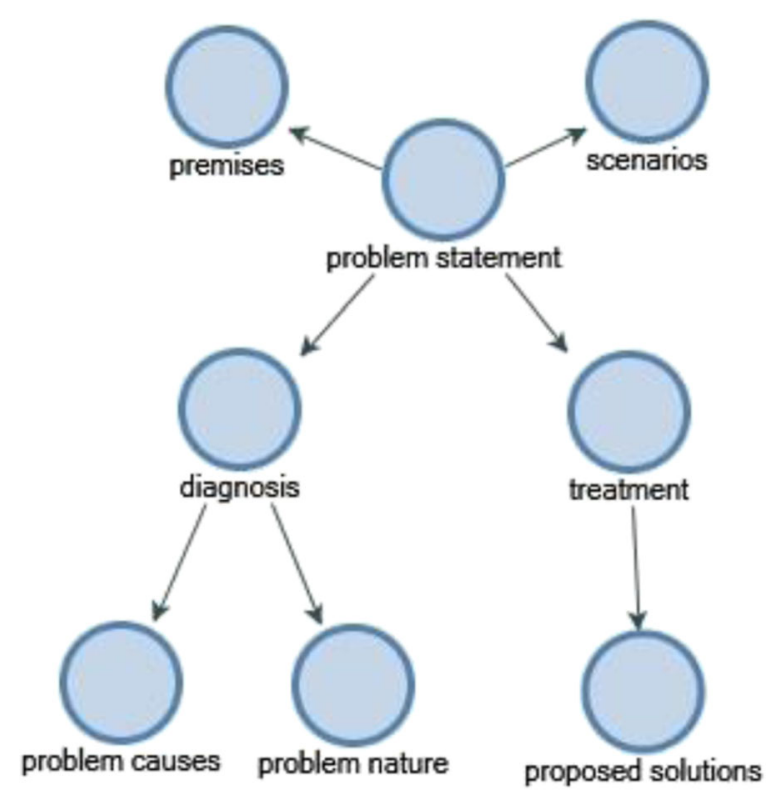

Fig. 2 Coding Map containing the main 'parent' and 'child' nodes used to code official documents. Source: Author's own elaboration using the software Nvivo

The coding list evolved and changed as research progressed and new insights and conceptual directions were revealed by the data, indicating important categories that should be aggregated, combined or withdrawn from the analysis (inductive approach). This means that the final coding scheme took several days to be completed and was followed by the constant annotation of decisions taken (see Additional file 2: Annex II).

The analysis of the coded data was done in two phases (Saldaña, 2013). The first was dedicated to the careful reading and interpretation of 'problem statements' in order to uncover the main narratives. The second concentrated on their comparison - in terms of time and institutional body - in order to identify possible counter-narratives and/or change.

\section{EU external migration policies and democratization of the southern Mediterranean neighbourhood: what nexus?}

Before describing the narratives uncovered and the nexus embedded in them, it is important to punctuate some general features concerning their nature. First, narratives have been dispersed and fragmented throughout EU official documents, appointing no clear pattern to

"The European Union needs a comprehensive approach to migration

addressing political, human rights and development issues in countries and regions of origin and transit.

This requires combating poverty, improving living conditions and job opportunities, preventing conflicts and consolidating democratic states and ensuring respect for human rights, in particular rights of minorities, women and children. [...] Partnership with third countries concerned will also be a key element for the success of such a policy, with a view to promoting co-development]". (Council 1999). 'diagnosis' : what is believed to । be the main problem, that is, the I I nature (configuration) of the I problem and what is believe to be causing it (the drivers)

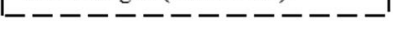

r | 'treatment': what are or should | I be the solutions, i.e. which I policies and strategies are or I should be implemented to solve the perceived problem.

Fig. 3 Example of coded 'problem statement'. Source: Author's own elaboration 
when and where references to this nexus are likely to be found. This lack of focus could be an indication that this link does not seem to be a priority to the EU, being solely rhetoric.

Secondly, although several documents refer to this nexus, some important ones do not make any explicit reference to it. An example is the recently issued European Agenda on Migration (Commission, 2015b). Consequently, even if narratives do exist, their inclusion within EU official discourse seems to be still a matter of ambiguity and controversy, especially if in comparison to the narratives of the migration-development and migration-security nexuses. An indication is that out of 143 documents, 43 have been coded under the child node 'root-causes-democratization', 86 under the 'rootcause-development' and 83 under the 'remote-control' one. This finding does not imply that narratives concerning the 'democratization-migration' nexus are less important, but it does suggest the prominence of the other two, as already indicated by the literature.

Another observation should be made regarding the definition of democracy. Since democratization refers mainly to the process through which countries achieve a democratic system, this is undeniably a key concept. In general, the EU conceives democracy positively and assumes it as a desirable goal. Moreover, democracy is usually associated with other values, mainly good governance, respect to the rule of law and human rights. However, it is interesting that even if conceived as a central value and an essential element of EU relations with the southern Mediterranean, democracy is neither straightforwardly defined in the documents analysed nor perceived as something that needs further explanation. This means that the EU is, to a certain extent, assuming its universality.

Despite this, researchers stress that there would be a deep disagreement between the EU and its partners in the South concerning the concepts of democracy and human rights (Aliboni, 2004). Such disagreement would not only be conceptual but also political, due to discrepancies in how to actually achieve it (ibid). It is argued that the EU conceives (liberal) democracy as a Western value leaving aside other (mainly Arab) narratives on democracy (Sadiki, 2004). In general, this is important because the lack of a clear definition of democracy on the one hand, and the lack of agreement and inclusion of other perspectives from the South on the other, has already been associated with EU shortcomings in terms of democracy promotion in the region (Jonasson, 2013).

\section{EU policy narratives before the 'Arab spring': lack-of-democracy-as-root-cause narrative}

From the analysis of 'problem statements' extracted from EU documents from 1995 to 2010, one dominant narrative could be identified. Within it, the main 'problem' the EU has been concerned with, was irregular and forced migration. Mainly, documents refer to the challenges posed by the 'massive arrival of immigrants' and the 'exodus of refugees' coming from or through southern Mediterranean countries. Both sorts of flows are portrayed as having destabilizing effects and posing security problems to the EU, although refugee flows are considered as less problematic.

Such 'problem' has been associated with many 'causes', among which 'structural causes' have been conceived as central ones. It is argued that irregular and forced migration is rooted in particular social, political and economic conditions in the countries of origin (push-factors). This means that alongside the more acknowledged economic drivers (i.e. poverty, unemployment) the $\mathrm{EU}$ also identifies political drivers as a main cause of population displacement in the region. 
On the one hand, dictatorship or lack of democracy and related factors such as poor governance, disrespect to the rule of law, human rights abuse, political persecution, generalized corruption etc., are believed to be at the source of migration flows from neighbouring Mediterranean countries:

"Ill-functioning democratic structures, weak institutions, the absence of the rule of law and bad governance are all major push factors for forced migration" (Commission 2002).

"Believes that massive immigration is a result of [inter alia] human rights violations [... ] political persecutions, political instability, corruption and dictatorships in many of the countries of origin" (Parliament, 2006).

On the other hand, lack of democracy is considered a source of instability and insecurity, conditions that have also been associated by the EU with the increase of irregular and forced migratory flows. In fact, the EU underlines the idea that political drivers are not independent but instead, they are linked with other drivers, such as poverty, development, stability, security, etc. The EU emphasizes the idea that migration has multiple and complex causes and for this reason should be addressed by a comprehensive approach (Parliament, 2006, 2007; Commission 2002, 2006). This means that autocracies or ill-functioning democracies would be one among many interlinked push-factors of migration.

If lack of democracy is perceived as a driver of migration, its advancement in the neighbourhood is seen as a central and favourable condition for EU goals of controlling migration at the source. Thus, a main argument found within EU narrative is that such structural condition in sending countries should be a matter of concern. Already in 1995, the Commission argued that "Defending and promoting human rights is also a means of tackling the huge movements of population which are caused by crisis and conflict" (Commission, 1995). Similarly, in 1999 it was stated in a European Council that:

"The European Union needs a comprehensive approach to migration addressing political, human rights and development issues in countries and regions of origin and transit. This requires [... ] consolidating democratic states and ensuring respect for human rights, in particular rights of minorities, women and children" (European Council, 1999).

The Parliament also defended the necessity of supporting the consolidation of democracy in third countries for achieving these same goals in the report on the Creation of the High Level Working Group (Parliament, 2000).

Apart from being an end in itself, since it would address structural political drivers of migration, democratic development is considered to be source of stability, security and peace, conditions that are also positively associated by the EU with the decrease of migration flows. Likewise, democratization could also eventually lead to more development - which would mean addressing socio-economic drivers, such as poverty, unemployment and inequality.

The importance of these policy areas and the inter-links between them become even more evident when considering the main policy frameworks for cooperation in the EuroMediterranean area. Both the launch of the Barcelona Process in 1995 and the European 
Neighbourhood Policy [ENP] in 2004 had within their main goals the promotion of stability, security and prosperity in the region. A necessary condition for the fulfilment of these goals would be strengthening democracy and respect for human rights. As a result, both initiatives had within their core the promotion and support for democracy in the neighbourhood (Barcelona Declaration, 1995; Commission, 2005a, 2004). The ENP specifically, when announced, created many prospects for democracy promotion (Khakee, 2010), to the point of being conceived as the Union 'newest democratization tool' (Barbé \& Johansson-Nogués, 2008). Regardless of the actual fulfilment of these goals, the idea of creating a "ring of well governed countries" (Commission 2004) is key for EU's objective of promoting stability and prosperity in its Southern neighbourhood and consequently, in its borders.

Finally, two important ideas about the future (scenarios) found in the EU narrative seem to have helped configuring and reinforcing the narrative. The first scenario is that irregular migration is not expected to decrease; on the contrary, it is set to continue or even accelerate, mainly because it is rooted in structural features of the Mediterranean that are unlikely to disappear in the short-term (Commission 2002). This prognostic reinforces the argument of applying long-term and comprehensive solutions tackling the structural drivers of migration, among which lies the promotion of democratization.

The second scenario is related to the successive migration 'crises' and the raise of migrants death toll. In particular, two 'crises' had a symbolical impact in the narrative and triggered policymaking processes within the EU in the middle 2000's. The first one occurred mainly during 2005, when the number of migrants crossing the fenced borders of Ceuta and Melilla (two Spanish enclaves in the Northern coast of Morocco) raised considerably ("5 African migrants killed and scores," 2005; "Under fire at Europe's border," 2005). In this process, several migrants ended up severely injured and 13 were reported $\mathrm{dead}^{7}$ due to the excessive force and use of 'dissuasive' equipment by the police at both sides of the border. The second one, known as the 'cayucos crisis', happened in 2006, when more than 31,000 migrants (a record number) reached the Canary Islands successfully after sailing the Atlantic from the shores of Mauritania and Senegal in fishing boats (cayucos). Spanish immigration officials estimated that at least 6000 people have died or gone missing while attempting to make this risky crossing during this same period ("Canaries migrant death toll soars," 2016).

At this point and in face of these scenarios, the EU started perceiving the situation of irregular and forced migration with a sense of urgency, underlining the necessity of taking action and stopping the human tragedy that was taking place in its borders. Already in 2005, which coincided with the 10th anniversary of the Barcelona Declaration (Commission, 2005a), the EU launched the Global Approach to Migration (GAM) (Council, 2005). This new framework intended to respond to the need for a balanced, global and coherent approach that could face the short-term challenge of reducing illegal immigration and the loss of lives and at the same time recognize the importance of tackling the root-causes of migration (Ibid). As a result, the EU defended the necessity of not only

\footnotetext{
${ }^{7}$ According to newspapers and NGOs reports, most migrants died from injuries caused by shots with live ammunition and one died from injuries caused by a rubber bullet (Amnesty International, 2006). Both Spanish and Moroccan authorities have neither claimed nor been hold responsible for these killings ("Melilla: Europe's dirty secret," 2010), which the EU referred to as 'tragic events' (Commission, 2005b). ${ }^{8}$ The revision was already ongoing before the advent of the Arab uprisings; however, these events made it more pertinent (Delcour \& Soler i Lecha, 2018).
} 
'combating' but also 'preventing' these flows putting emphasis on the "urgent need to combat the root-causes of migration" (Paris Declaration, 2008).

Therefore, the nexus observed in the dominant narrative could be summarized as it follows (see Fig. 4): the EU perceives lack of democracy as a root-cause of migratory and refugee flows. This means that EU promotion and support to democratic consolidation in 'sending' countries in the southern Mediterranean is believed to contribute to addressing the migratory 'problem' - i.e. irregular and forced migration - since it addresses the main structural factors causing and perpetuating it, directly or indirectly. This means that the EU considers democratization as part of its 'solution pack' within its migration policy goals and strategies.

\section{EU policy narratives post- 'Arab spring' \\ The first years (2011-12): continuity despite change}

At the time that the 'Arab spring' in 2011 started to unfold, transforming the political and social landscape of the Mediterranean, the core story sustained by the EU continued to be the same. Irregular and forced migration remained a central problem for the EU that ought to be fought and prevented. Similarly, lack of democracy continued to be professed as an important structural push-factor of migration and refugee flows.

For this reason, providing a solution to this problem would pass through supporting the democratization processes unfolding in the southern Mediterranean. In fact, EU first reactions to the Arab uprisings were actually in this line, reinforcing the existing narrative. Among EU main initiatives was the launch of the "Partnership for Democracy and Shared Prosperity" (Commission, 2011a), which was an intent to take a qualitative step forward in EU relations with its southern neighbours and to provide short-term support to the democratic change unfolding in the region (Bauer, 2015). Under this new framework, the EU reconceptualised democracy and redesigned its strategy for democracy promotion.

Another development in this direction was the revision of the ENP in $2011^{8}$. An important aspect of this revision is related to the introduction of a 'new policy' of conditionality: the 'more for more' approach (Pace, 2014), which is embedded in the ENP idea of implementing a positive conditionality tool (Abdalla, 2016). According to this

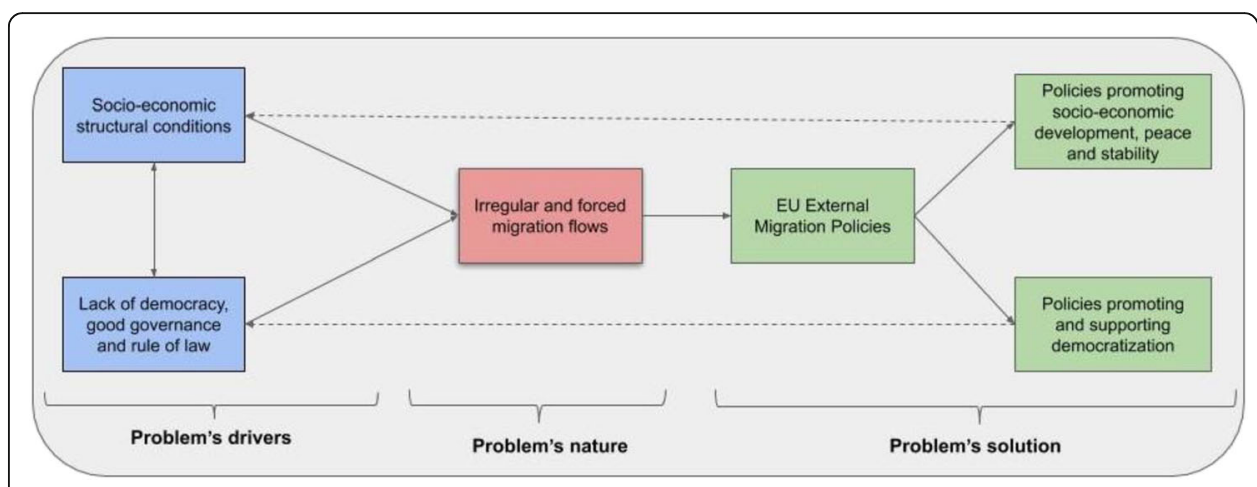

Fig. 4 Nexus configuration between EU external migration policy and democratization of Southern Mediterranean (pre-'Arab spring): lack-of-democracy-as-root-cause narrative. Source: Author's own elaboration 
policy, the EU would be willing to offer the 'three Ms' (money, mobility and market) to countries that advanced significantly in terms of political reforms:

"Increased EU support to its neighbours is conditional. It will depend on progress in building and consolidating democracy and respect for the rule of law. The more and the faster a country progresses in its internal reforms, the more support it will get from the EU" (Commission, 2011b).

Here it is already possible to spot some small changes in the narrative due to the introduction of new elements in the proposed solutions, which apart from not modifying its core elements, have even worked to reinforce them. First, the idea of building a stronger partnership with the people, mainly through giving greater support to the civil society in Mediterranean countries was introduced (Commission, 2011b). Second, promoting people-to-people contact across the Mediterranean was proposed as a way to support burgeoning democratisation in North Africa (Commission, 2011c, 2011d, 2011e). In other words, the EU should enhance the positive effects of migration in terms of promoting human development and democracy in fragile states (Parliament, 2011a). In fact, at this point the GAM was renewed, becoming the Global Approach to Migration and Mobility (Commission, 2011e). This updated version reaffirmed the externalized approach introduced in 2005, giving enhanced focus on better organizing and promoting mobility of third country nationals (ibid). Finally, a special emphasis has also been given to the role of the youth in the process of democratization (Commission, 2012; Council, 2012).

At this point, it seems that the events unfolding in the region provided an empirical validation of the dominant narrative, reinforcing the need for promoting democracy in order to stem and prevent irregular and forced migration. Thus, in a certain sense, these events led to a continuity of the narrative despite the changes unfolding in the region, marking the "re-launch of EU 'normative ambitions' for the Arab countries" (Seeberg, 2015, p. 41; Bauer, 2015).

\section{The aftermath of the 'Arab spring' and the 'migration crisis': towards a narrative dualism}

As previously described, the first years of the 'Arab spring' created opportunities for strengthening the dominant narrative. However, some key variations could already be perceived in the years that followed the revolutions and especially in the context of the so-called 'migration crisis'.

An important element of change concern the nature of the problem. Although the idea of 'mass influx' of migrants has always been present in the EU narrative, from 2015 onwards it gained a new input. This is closely related to the perception of flows as being uncontrolled, growing and mixed (i.e. as containing both displaced people and economic migrants). Moreover, since then, the EU stresses to be facing a crisis configured by an "unprecedented influx" of migrants, referring to it as the "biggest refugee crisis since the WWII". In fact, Geddes and Hadj-Abdou (2018) emphasized how the

\footnotetext{
${ }^{8}$ The revision was already ongoing before the advent of the Arab uprisings; however, these events made it more pertinent (Delcour and Soler i Lecha, 2018).
} 
use of the word crisis would reflect EU difficulties for dealing with this 'new' context in the neighbourhood and the necessity of providing solutions accordingly. At the same time, these authors also highlighted how the EU started perceiving this reality of external migratory pressure as the 'new normal', that is, as something that is unlikely to change in the near future.

Concerning the causes of these migratory flows, the EU places a new emphasis on the instability variable, which would arise from the contexts of war, armed conflicts, violence as well as situations of political and economic crises that could be appreciated all across the Mediterranean at the time. This means that structural factors are complemented with other drivers believed to be more 'circumstantial' and 'transitory'. Another novelty is that the EU seems to be concerned with sources of instability that might come from outside the security domain, such as poverty, sense of injustice, corruption, and a general lack of social and economic development in countries of origin, especially among the youth (Commission, 2015a). Most importantly, these destabilizing socioeconomic conditions are believed to be exacerbated in a situation of lack of democratic principles (Parliament, 2011a, 2011b).

In this context, supporting and promoting democracy (and related values) in the Mediterranean is still conceived as a solution to the migration problem not only because it would address structural political conditions in the region, but also because it would be a way of tackling instability and insecurity:

"Migration flows arising from instability are a challenge for the European Union.

Wars and armed conflicts, ethnic tension, systematic violations of human rights such as the refusal to allow people to practise their religious faith - natural disasters and the lack of proper economic and democratic structures are the main causes of this type of migration flow" (Parliament 2015).

Considering this new scenario, it could be argued that the dominant narrative has changed slightly in comparison to the two other periods aforementioned; mainly due to the increased emphasis on the elements of crisis and instability, which moved to the centre of the narrative. Still, it should also be noticed that the narrative's core elements and causal logic have remained the same. This clearly indicates that lack of democracy continued to be framed as a root-cause of migration despite the introduction of these mediating variables (see Fig. 5).

The analysis revealed that this new context not only led to the reconfiguration of the dominant narrative but has also led to the emergence of a 'different' and 'contradictory' narrative, whose core arguments runs counter the ones found so far in the dominant narratives. Mainly, the EU started to link the historic events unfolding in the region the Arab uprisings - with the unprecedented augmentation of migration flows heading towards Europe.

Even if not explicitly mentioned, behind this argument is the idea of refugee hump. Similar to the phenomenon of migration hump, according to which successful development would induce more and not less migration (Commission 2002), refugee hump explains how "democratization" and "democracy promotion" may lead to an increase in migratory flows. This is mainly because processes of democratization and political change may be a source of instability, social upheaval and uncertainty and, at least in the short/medium term, produce an escalation in forced migration (Schmeidl, 2001 


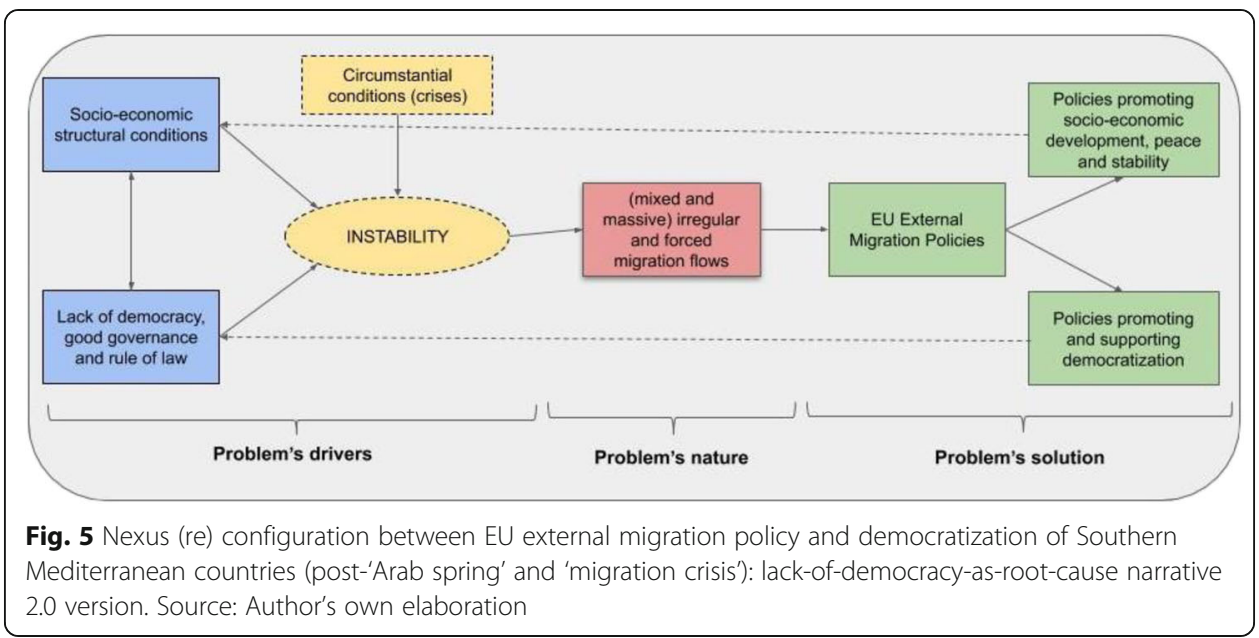

quoted by van Hear \& Sørensen-Nyberg, 2002). However, differently from the literature, the EU considers these processes as key drivers of both 'forced' and 'irregular' (i.e. 'voluntary') migration. Some fragments extracted from Commission documents help illustrating how the EU constructs this argument:

"The events in the Southern Mediterranean bring hope for a better life for millions of people in our neighbourhood, as well as for greater respect of human rights, pluralism, the rule of law and social justice. As is often the case for democratic uprisings, they may also entail, in the short and medium term, upheaval and uncertainty. Political unrest and military conflicts have led to the loss of human lives and the displacement of hundreds of thousands of people [... ]" (Commission, 2011c).

"[ ... ] policies need to address the different root causes of irregular and forced migration, inter alia political change and instability" (Commission, 2014).

"Over the past ten years, there have been significant political developments in the neighbourhood. Today's neighbourhood is less stable than it was ten years ago. [ ... ] These events have served to increase the challenges faced by both the EU and its partners, aggravating economic and social pressures, irregular migration and refugee flows, security threats and leading to diverging aspirations (Commission, 2015a)".

Although it cannot be said that democratization stopped being a desirable goal, there is at least a perception that the EU should be cautious when supporting this process, since it may have the undesirable effect of producing more instability, and, consequently, more migration (refugee hump). Therefore, based on this argument, the idea of postponing the promotion of democracy and good governance to the longer-term becomes even more evident and easy to sustain rhetorically. Meanwhile, in the shorter-term, the EU can focus on addressing instability and stemming migration flows arising from it through rapid solutions. 
The emphasis on promoting stability can be appreciated by looking into two key policy developments that happen alongside 2015. The first one was the launching of the EU Emergency Trust Fund for Africa for stability and addressing root causes of irregular migration and displaced persons (Council, 2015). Within the Trust Fund top priorities lies enhancing stability and governance, which should be achieved by promoting conflict prevention, security and rule of law enforcement. It is important to underline that the focus on state building here is mainly thought as a way of improving border and migration management (i.e. stemming migration), and not as a tool for promoting democracy. Most interestingly, through this policy, 'strengthening the resilience of vulnerable people' arises as a key priority that will gain increasing attention and centrality in subsequent policy initiatives (Council, 2015). The second development worth highlighting is the fact that the ENP underwent another strategic revision during 2015, in which stabilization was reinforced as the main political priority that should be tackled across sectors, "making partner countries places where people want to build their future, and help tackle uncontrolled movement of people" (Commission, 2015a, p. 4).

In sum, it can be observed that within this counter-narrative the nexus between EU external migration policies and democratization contradicts what has been identified so far in the other narratives, mainly because the causal logic is completely inverted. In this case, democratization is not viewed as a solution to irregular and forced migration. Contrarily, it is framed as a potential driver (push-factor) of this problem since it can eventually lead to destabilization (uprisings, insecurity and even conflict) in the short term and unleash an influx of forced and irregular migration (refugee hump) (see Fig. 6). As a result, the solutions envisioned would not pass through supporting further democratization, as sustained by the dominant narrative, but through prioritizing the stability and security in the region.

\section{A truly polarized issue?}

Apart from their overall configuration and differences over time, the analysis has also revealed how EU actors (mainly the Commission, the Parliament and the Council) cast different narratives and had divergent perceptions of this nexus and its importance within EU broader strategy.

Although it is true that there seems to be a convergence towards one dominant narrative (lack-of-democracy-as-a-root-cause), EU institutional bodies seem to differ in how they refer to it. In the case of the Council, it has not been surprising to observe that this body rarely makes explicit reference to this nexus; indicating that this narrative has not been a priority. Moreover, when mentioning it, the Council tends to avoid

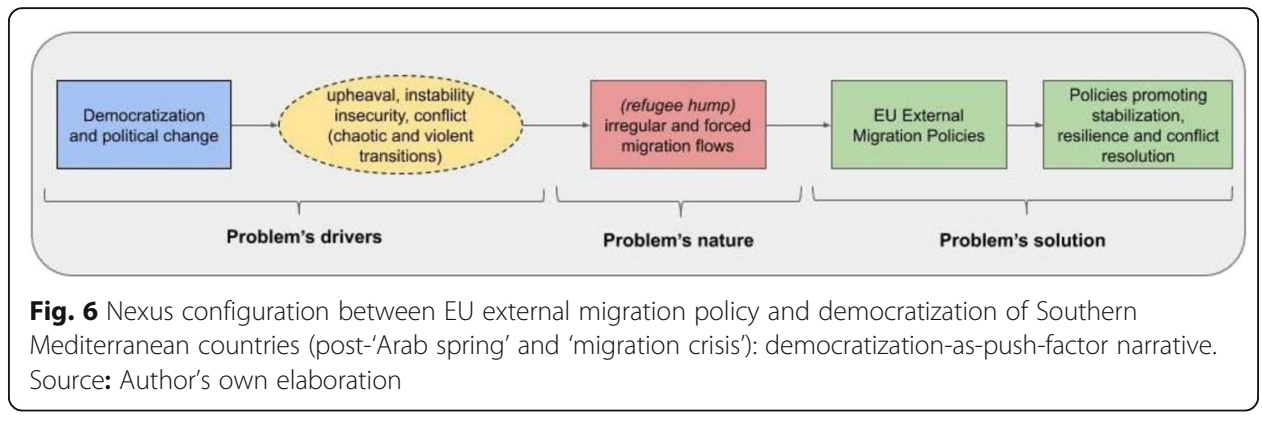


using words like 'democratization' and 'dictatorship', giving preference to less politically charged terms and repeating the ambiguous 'good/poor governance mantra':

"tackling the root causes of migration, for example through the creation of livelihood opportunities [... ] and promotion of economic growth, good governance and the protection of human rights" (Council, 2005).

The Council confirms its commitment to mobilise all appropriate instruments and policies and support efforts to address the root causes of migratory flows, in particular conflicts, political instability, human rights violations, poor socio-economic development, including lack of employment opportunities, poor governance and climate change (Council, 2015).

The Parliament, in contrast, has been much clearer when referring to this nexus. In fact, it is the main actor making straightforward statements appointing to the lack of democracy and dictatorship as important structural factors behind migration flows. Likewise, it also refers to the promotion of democratization in the Southern Neighbourhood as an essential solution in several occasions. This would be in line with the normative historical role associated to the Parliament, which would be the 'symbol of democracy' in Europe and the 'loudspeaker for basic democratic rights' (Feliu \& Serra, 2015, p. 30). A role that is not only externally appointed but also selfascribed: "the key importance of the European Parliament in enhancing freedom and democracy in our neighbourhood; in this context, believes that the European Parliament should monitor closely the democratisation process in the southern Mediterranean" (Parliament, 2011a).

Moreover, the Parliament has been particularly critical and concerned with the role of other EU institutional bodies when incorporating and addressing this nexus. It emphasizes the importance of maintaining an inter-institutional dialogue on the matter, denouncing the lack of communication and feedback, especially between the Parliament and the Council (Feliu \& Serra, 2015; Parliament, 2011b). It has also been critical towards other EU bodies, such as the Commission and the EEAS, calling them to make "further efforts with regard to the development and democratisation of countries of origin and to promote the rule of law, in order to tackle the problems associated with migration at their root" (Parliament, 2011a; Parliament, 2016a). Finally, this body has been particularly concerned with the possible divergence of development and democratization funds towards the goal of stemming migration (Parliament, 2016a), such as using Official Development Assistance (ODA) for policies aimed at deterring and controlling migration (Parliament, 2016b).

Alongside the Parliament, the Commission has also been a protagonist in casting the dominant narrative on this matter. However, this actor seems to be more sceptical in relation to the effectiveness of policies promoting human rights and democracy on addressing the root-causes of migration. This is somehow related to the fact that pushfactors are considered to be complex and unlikely to disappear (Commission, 2006). For this reason, the promotion of democracy and related values is conceived mainly as a complementary tool of migration control instead of as a central one. Moreover, despite agreeing with the Parliament in many instances, the Commission 
has been casting stories that might be contradictory to the dominant narrative, mainly the one relating political changes with increased migration flows (democratization-as-push-factor narrative).

Considering the aforementioned, it could not be affirmed that within the EU this nexus constitutes a truly polarized issue, mainly because most of the times narratives are either absent or tend to converge. Nonetheless, we can still spot some different and even contradictory stories coming from various institutional voices. This would confirm the ambivalence and inconsistencies of the EU external migration action, something that has been already underlined by the literature (Lavenex, 1999; Richey 2012; Geddes \& Lixi, 2018). In particular, the Parliament holds a much more critical perspective when addressing the democratization-migration nexus in comparison to the Commission and the Council, which are, in fact, the main institutional bodies in the driver's seat of the EU external migration policies. This indicates that if the Parliament was to be given its real share of power in the formulation of these policies, as stipulated in the Treaty of Lisbon, one could expect the narratives concerning this nexus to gain more prominence.

\section{Discussion and conclusions}

Through a Narrative Policy Analysis of EU official documents from 1995 to 2018, this article explored EU stories and arguments on the linkages between EU external migration policies and the democratization of countries in the southern Mediterranean neighbourhood. In general, the analysis of coded statements and time comparison allowed for revealing how the EU (and its institutional bodies) understood the configuration of this nexus and framed the causal links between these processes, exposing EU beliefs and premises attached to it (see Table 1).

Firstly, the analysis exposed that despite the dispersion, divergences among EU institutional bodies and the subtle changes suffered throughout the years, the lack-of-democracy-as-a-root-cause narrative has been present since the inception of the Barcelona Process. This finding confirms the idea that there is, at least rhetorically, an important normative component within EU external migration policies; something to be expected considering the EU self-perception and external projection as a normative power. However, considering the little effort the EU makes in practice to advance democracy in the region (Bicchi, 2010; Youngs, 2001), one could question if the EU would make a functional use of this rhetoric. That is, to use its internationally recognized role as a normative power for supporting higher political objectives (migration control), rather than as an end in itself (Limam \& Del Sarto, 2015).

Secondly, the analysis has also uncovered some narrative shifts in the post-'Arab Spring' momentum. The most revealing one was the appearance of a competing and symmetrically opposite narrative in the context of the 2015-2016 'migration crisis' (democratization-as-a-push-factor). The emergence of this counter-narrative can be better understood in light of the stability-democratization dilemma that curtails and conditions EU democracy promotion in the region (Börzel, 2015; Börzel, Risse, \& Dandashly, 2015). This dilemma explains that despite being an explicit goal in its foreign policy, the EU does not engage in democracy promotion at all costs. On the contrary, the EU tends to prioritize security and stability over democratic change (Ibid), the 'master-frame' shaping EU actions in the region (Roccu \& Voltolin, 2018). 
Table 1 The nexus between EU external migration policies and democratization: policy narrative comparison (1995-2018)

\begin{tabular}{|c|c|c|c|}
\hline Narratives & Problem's driver & Problem's nature & Problem's solution \\
\hline \multicolumn{4}{|c|}{ Pre-'Arab spring' ( 1995-2010) } \\
\hline $\begin{array}{l}\text { Dominant narrative: } \\
\text { lack-of-democracy- } \\
\text { as-root-cause }\end{array}$ & $\begin{array}{l}\text { lack of democracy, rule of law, } \\
\text { good governance }\end{array}$ & $\begin{array}{l}\text { irregular and forced } \\
\text { migration flows }\end{array}$ & $\begin{array}{l}\text { promoting and } \\
\text { supporting } \\
\text { democratization }\end{array}$ \\
\hline \multicolumn{4}{|c|}{ First years post-'Arab spring' ( 2011-12) } \\
\hline $\begin{array}{l}\text { Dominant narrative: } \\
\text { lack-of-democracy- } \\
\text { as-root-cause }\end{array}$ & $\begin{array}{l}\text { lack of democracy, rule of law, } \\
\text { good governance }\end{array}$ & $\begin{array}{l}\text { irregular and forced } \\
\text { migration flows }\end{array}$ & $\begin{array}{l}\text { (short-term) } \\
\text { promoting and } \\
\text { supporting } \\
\text { democratization }\end{array}$ \\
\hline \multicolumn{4}{|c|}{ Post-'Arab spring' and the 'migration crisis' ( 2015-2018) } \\
\hline $\begin{array}{l}\text { Dominant narrative: } \\
\text { lack-of-democracy- } \\
\text { as-root-cause }\end{array}$ & $\begin{array}{l}\text { lack of democracy, rule of law, good } \\
\text { governance }+ \text { (intervening variable) } \\
\text { instability and crisis }\end{array}$ & $\begin{array}{l}\text { (massive and mixed) } \\
\text { irregular and forced } \\
\text { migration flows }\end{array}$ & $\begin{array}{l}\text { (long-term) promoting } \\
\text { and supporting } \\
\text { democratization }\end{array}$ \\
\hline $\begin{array}{l}\text { Counter-narrative: } \\
\text { democratization-as- } \\
\text { push-factor }\end{array}$ & $\begin{array}{l}\text { democratization and political change } \\
+ \text { (intervening variable) instability, } \\
\text { insecurity and conflict }\end{array}$ & $\begin{array}{l}\text { (refugee hump) } \\
\text { irregular and forced } \\
\text { migration flows }\end{array}$ & $\begin{array}{l}\text { promoting } \\
\text { stabilization, conflict } \\
\text { resolution, resilience }\end{array}$ \\
\hline
\end{tabular}

Source: Author's own elaboration

Therefore, one could conclude that these narrative shifts occurred as a consequence of the EU growing foreign policy pragmatism towards the region in face of the wave of instability and, mainly, migratory flows unleashed in the aftermath of the 'Arab spring'. Although this per se cannot be considered as an unexpected finding, what does seem to be a novelty is the insertion of the migration variable in the democratization-stability dilemma. Throughout its history, Western powers have cast different stories to justify prioritizing stability and security over democratization (e.g. to avoid the instauration of communist regimes in Latin America). In the context of contemporary EuroMediterranean relations, the menace of a refugee hump seems to be playing such role in this equation. Thus, it would not be the risk of destabilization per se, but its association with migration flows that would prevent the EU from engaging more proactively (or at all) in democracy promotion in the region.

The fact that such counter-narrative only became evident after the 'migration crisis' should not pass unnoticed either. Its late appearance might be related to the fact that only within this new context the arguments defended in this narrative became easier to sustain. However, even then, this narrative did not seem to become really explicit and pervasive within EU's political discourse. This is confirmed by the difficulty to find official documents where such story is expressed in a straightforward manner. Thus, it could be questioned the extent to which such narrative has been more an implicit story than an official narrative - likely to have always been present in EU policy strategy although absent from EU rhetoric.

In general, besides identifying the main narratives, the analysis has also exposed the high uncertainty, complexity and ambiguity concerning the nexus between democratization and EU migration policies. A definitive indication of this is the fact that, at least in the context of the 2015-16 'migration crisis', two antagonistic stories seemed to co-exist. This should lead us to reflect upon EU strategies for reconciling and balancing these contradictory narratives. Even though choosing to keep a certain lack of clarity in the narrative might fulfil a strategic political goal, this course of action will not prevent the EU from being accused of ambiguity and hypocrisy, something that 
will continue to undermine its credibility and legitimacy in terms of democracy promotion in the region (Börzel, 2015).

A further related observation has been that although it cannot be considered as a truly polarized issue, the analysis has revealed the existence of different and even contradictory stories among EU institutional bodies. Roe (1994) claims that certain levels of uncertainty ('certainties of uncertainty' as he describes it) have a functional role of enabling decision making whereas the reduction of uncertainty might freeze it. Thus, one could conclude that the levels of uncertainty and complexity contained in the narratives could be part of a political strategy for allowing decision-making in a situation of many unknowns, relative polarization and high pressure.

In methodological terms, two main backdrops of this study should be acknowledged. On the one side, the focus on written narratives and public documents as the only source of data has important limitations. This is mainly because the type and quantity of published documents clearly serves a function that is not necessarily related to EU priorities, but rather to internal, bureaucratic and political strategies. On the other, the analysis did not pay enough attention to the subtler emotional and symbolical dimensions of narratives. This other perspective would have given more depth to the analysis in comparison to the general argumentative structures contained in the 'problem statements' analysed. This could be achieved by focusing on different analytical structures, by applying other methodologies, such as critical discourse analysis, or by interviewing political actors directly.

A final reflection would be that as in the case of the migration-development and migration-security nexuses, the migration-democratization nexus needs to be revised, mainly through the deconstruction of the purposes and interests behind it (Lavenex \& Kunz, 2008). This would be possible through understanding the extent to which these policy narratives have been legitimating power relations and hierarchies, not only within the EU but also concerning Mediterranean geopolitical relations. For this, it would be necessary to study how these narratives have been currently unfolding on the ground, that is, to examine what have been the impacts of EU migration policies on the targeted countries on the South. This would be essential for further comprehension of the many stories and contradictions behind EU external migration policies.

\section{Supplementary information}

Supplementary information accompanies this paper at https://doi.org/10.1186/s40878-019-0165-z.

Additional file 1: Annex I. Complete list of EU Official Documents.

Additional file 2: Annex II. Complete coding map.

Abbreviations

ENP: European Neighbourhood Policy; EU: European Union; NPA: Narrative Policy Analysis

Acknowledgements

Not applicable.

Author's contributions

LFT have read and approved the final manuscript that is being submitted.

Funding

There is no specific source of funding to be declared. 
Availability of data and materials

All documents used and/or analysed during the current study are available online. More information about the analysis can be provided upon request.

\section{Competing interests}

The author declares no competing interests with respect to the research, authorship and publication of this article.

Received: 29 December 2018 Accepted: 22 October 2019

Published online: 17 February 2020

\section{References}

5 African migrants killed and scores hurt at Spanish enclave fence. (2005, September 5). The New York Times. Retrieved from https://www.nytimes.com/2005/09/30/world/europe/5-african-migrants-killed-and-scores-hurt-at-spanish-enclave. html.

Abdalla, N. (2016). The ENP between ambitions and delusions: Analysing Europe's misconceptions in supporting democratisation in Egypt(EuroMeSCo Series, No. 32). Retrieved from https://www.iemed.org/publicacions-en/historic-de-publicacions/ papersiemed-euromesco/32.-the-enp-between-ambitions-and-delusions-analysing-europe2019s-misconceptions-insupporting-democratisation-in-egypt.

Aliboni, R. (2004). Common languages on democracy in the Euro-Mediterranean partnership(EuroMeSCo Paper, No. 31). Retrieved from https://www.euromesco.net/wp-content/uploads/2017/10/200405-EuroMeSCo-Paper-1.31.pdf.

Amnesty International (2006). Spain and Morocco Failure to protect the rights of migrants - Ceuta and Melilla one year on (Index number: EUR 41/009/2006). Retrieved from https://www.amnesty.org/en/documents/eur41/009/2006/en/.

Aubarell, G., Zapata-Barrero, R., \& Aragall, X. (2009). New directions of National Immigration Policies: The development of the external dimension and its relationship with the Euro-Mediterranean process (EuroMeSCo Paper, No.79). Retrieved from https://www.euromesco.net/wp-content/uploads/2017/10/200902-EuroMeSCo-Paper-1.79.pdf.

Bacchi, C. (2009). The issue of intentionality in frame theory: the need for reflexive framing. In: E. Lombardo, P. Meier, M. Verloo (Eds.), The Discursive Politics of Gender Equality: Stretching, bending and policymaking. Abington and New York: Routledge, pp.19-35.

Barbé, E., \& Johansson-Nogués, E. (2008). The EU as a modest 'force for good': The European Neighbourhood policy. International Affairs, 84(1), 81

Barcelona Declaration (1995). Final Declaration of the Barcelona Euro-Mediterranean Ministerial Conference, 27-28 November 1995, Bull. EU 11/1995, at 136.

Bauer, P. (2015). The European Mediterranean policy after the Arab spring: Beyond values and interests. Middle East Critique, 24(1), 27-40.

Bicchi, F. (2010). Dilemmas in the implementation: EU democracy assistance in the Mediterranean. Democratization, 17(5), 976-996.

Börzel, T. (2015). The noble west and the dirty rest? Western democracy promoters and illiberal regional powers. Democratization, 22(3), 519-535.

Börzel, T., Risse, T., \& Dandashly, A. (2015). The EU, external actors, and the Arabellions: Much ado about (almost) nothing. Journal of European Integration, 37(1), 135-153.

Boswell, C. (2003). The external dimension of EU immigration and asylum policy. International Affairs, 79(3), 619-638.

Boswell, C., Geddes, A., \& Scholten, P. (2011). The role of narratives in migration policy-making: A research framework. British Journal of Politics and International Relations, 13(1), 1-11.

Brock, K., Cornwall, A., \& Gaventa, J. (2001). Power, knowledge and political spaces in the framing of poverty policy (IDS Working Papers No. 143). Retrieved from https://www.ids.ac.uk/publications/power-knowledge-and-political-spaces-in-the-framingof-poverty-policy/.

Canaries migrant death toll soars. (2016, December 28). BBC News. Retrieved from http://news.bbc.co.uk/2/hi/europe/6213495. stm.

Carrera, S., den Hertog, L., \& Parkin, J. (2013). The peculiar nature of EU Home affairs agencies in migration control: Beyond accountability versus autonomy. European Journal of Migration and Law, 15(4), 337-358.

Carrera, S., Radescu, R., \& Reslow, N. (2016).EU external migration policies: A preliminary mapping of the instruments, the actors and their priorities. Report prepared for the FP7 project 'transnational migration in transition: Transformative characteristics of temporary mobility of people' (EURA-NET), deliverable 3.1.

Cassarino, J. (2012). Reversing the hierarchy of priorities in EU-Mediterranean relations. In J. Peters (Ed.), The European Union and the Arab spring: Promoting democracy and human rights in the Middle East, (pp. 1-16). New York/Lanham: Lexington Books.

Commission (1995). The EU and the External Dimension of Human Rights Policy (COM, (95) 567). Brussels: European Commission.

Commission (2002). Integrating migration issues in the EUs relations with third countries (COM (2002) 703). Brussels: European Commission.

Commission (2004). European Neighbourhood policy: Strategy paper (COM (2004) 373). Brussels: European Commission.

Commission (2005a). Tenth Anniversary of the Euro-Mediterranean Partnership: A work programme to meet the challenges of the next five years (COM, 2005, 139). Brussels: European Commission.

Commission (2005b). Visit to Ceuta and Melilla - Mission report technical mission to Morocco on illegal immigration (MEMO/05/ 380). Brussels, European Commission.

Commission (2006). On Policy priorities in the fight against illegal immigration of third-country nationals (COM (2006) 402, final). Brussels: European Commission.

Commission (2011a). A Partnership for Democracy and Shared Prosperity with the Southern Mediterranean Neighbourhood (COM (2011) 200). Brussels: European Commission.

Commission (2011b). New response to a changing neighbourhood (COM (2011) 303). Brussels: European Commission.

Commission (2011c). Communication on Migration (COM (2011) 248 final). Brussels: European Commission. 
Commission (2011d). A dialogue for migration, mobility and security with the southern Mediterranean (COM (2011) 292). Brussels: European Commission.

Commission (2011e). The Global Approach to Migration and Mobility (COM (2011) 743). Brussels: European Commission. Commission (2012). Supporting closer cooperation and regional integration in the Maghreb: Algeria, Libya, Mauritania, Morocco and Tunisia (JOIN (2012) 36). Brussels: European Commission.

Commission (2014). An open and secure Europe (COM (2014) 154). Brussels: European Commission.

Commission (2015a). T owards a new European Neighbourhood Policy (JOIN (2015) 6). Brussels: European Commission.

Commission (2015b). A European Agenda on Migration (COM (2015) 240). Brussels: European Commission.

Cornwall, A., \& Brock, B. (2005). What do buzzwords do for development policy? A critical look at 'participation', 'empowerment' and 'poverty reduction'. Third Would Quarterly, 26(7), 1043-1060.

Council (2005). Brussels European council presidency conclusions - 'global approach to migration' (GAM). Brussels: Council of the European Union.

Council (2012). Council Conclusions on the Global Approach to Migration and Mobility (9417/12). Brussels: Council of the European Union.

Council (2015). Valletta summit on migration - Action plan. Valletta: European Council.

Delcour, L., \& Soler i Lecha, E. (2018). European Neighbourhood Policy Mechanisms: conditionality, socialization and differentiation. In T. Schumacher, A. Marchetti, \& T. Demmelhuber (Eds.), The Routledge Handbook on the European Neighbourhood Policy, (pp. 445-455).

European Council (1999). Presidency conclusions of the Tampere European council. Brussels: European Council.

Feliu, L., \& Serra, F. (2015). The European Union as a 'normative power' and the normative voice of the European Parliament. In S. Stavridis, \& D. Irrera (Eds.), The European Parliament and its international relations, (pp. 17-34). London/New York: Routledge.

Fernández-Molina, I. (2018). The neighbourhood policy and EU-Maghreb relations. In T. Schumacher, A. Marchetti, \& T. Demmelhuber (Eds.), The Routledge handbook on the European neighbourhood policy, (pp. 324-333). Oxon: Routledge.

Fratzke, S., Salant, B. (2018). Moving Beyond "Root-Causes": The complicated relationship between development and migration. Migration Policy Institute.

Geddes, A., \& Hadj-Abdou, L. (2018). Changing the path? EU migration governance after the 'Arab spring'. Mediterranean Politics, 23(1), 142-160. https://doi.org/10.1080/13629395.2017.1358904.

Geddes, A., \& Lixi, L. (2018). New actors and new understandings in European Union external migration governance? The case of EU- Tunisian migration relations. In C. Carrera, D. Kostakopoulou, \& M. Panizzon (Eds.), The external faces of EU migration, Borders and asylum policies: Intersecting policy universes. Leiden: Brill.

Gent, S. (2002). The root causes of migration: Criticising the approach and finding a way forward (Sussex migration Working Paper No. 11). Sussex: Sussex Centre for Migration Research.

Guiraudon, V. (2003). The constitution of a European immigration policy domain: A political sociology approach. Journal of European Public Policy, 10(2), 263-282.

Jonasson, A. (2013). The EU's democracy promotion and the Mediterranean Neighbours: Orientation, ownership and dialogue in Jordan and Turkey. Oxford: Routledge.

Kaplan, T.J. (1986). The Narrative Structure of Policy Analysis. Journal of Policy Analysis and Management, 5(4), p. 761.

Keeley, J., \& Scoones, I., (2003). Understanding Environmental Policy Processes: Cases from Africa. London: EARTHSCAN Publications Ltd.

Khakee, A. (2010) Assessing democracy assistance: Morocco (Project Report Assessing Democracy Assistance). Fride.

Lavenex, S. (1999). Safe third countries: Extending the EU asylum and immigration policy to South Eastern Europe. Budapest: Central European University Press.

Lavenex, S. (2006). Shifting up and out: The foreign policy of European immigration control. West European Politics, 29(2), 329-350.

Lavenex, S., \& Kunz, R. (2008). The migration-development Nexus in EU external relation. Journal of European Integration, 30(3), 439-457.

Limam, M., Del Sarto R. A. (2015). Periphery under pressure: Morocco, Tunisia and the European Union's mobility partnership on migration (EUI Working Papers, RSCAS 2015/75), Borderlands Project.

Manners, I. (2002). Normative power Europe: A contradiction in terms? Journal of Common Market Studies, 40(2), 235-258.

McBeth, M. K., Shanahan, E. A., Arnell, R. J., \& Hathaway, P. L. (2007). The intersection of narrative policy analysis and policy change theory. Policy Studies Journal, 35(1), 87-108.

Pace, M. (2014). The EU's interpretation of the 'Arab uprisings': Understanding the different visions about democratic change in EU-MENA relations. Journal of Common Market Studies, 52(5), 969-984.

Paris Declaration (2008). Joint Declaration of the Paris Summit for the Mediterranean. Paris: European Union, 13 July 2008, at 1.

Parliament (2000). Report on asylum-seekers and migrants - action plans for countries of origin or transit (High Level Working Group, A5-0057/2000). Brussels: European Parliament.

Parliament (2006). European Parliament resolution on the EU common immigration policy (P6_TA(2006)0386). Brussels: European Parliament.

Parliament (2007). Report on the Policy Plan on Legal Migration (A6-0322/2007). Brussels: European Parliament.

Parliament (2011a). Report on migration arising from instability: scope and role of EU foreign policy. A7-0075/2011. Brussels: European Parliament.

Parliament (2011b). Migration flows arising from instability: Migration flows arising from instability: scope and role of the EU foreign policy (P7_TA (2011) 0121). Brussels: European Parliament.

Parliament (2015). Extraordinary European council meeting (23 April 2015) - the latest tragedies in the Mediterranean and EU migration and asylum policies (P8_TA (2015) 0176). Brussels: European Parliament.

Parliament (2016a). The situation in the Mediterranean and the need for a holistic approach to migration (A8-0066/2016). Brussels: European Parliament.

Parliament (2016b). Report on human rights and migration in third countries (A8-0245/2016). Brussels: European Parliament.

Pinyol-Gimenez, G. (2012). The migration-security Nexus in short: Instruments and actions in the European Union. Amsterdam Law Forum, 4, p. 36. VU University Amsterdam.

Richey, M. (2012). The north African revolutions: A chance to rethink European externalization of the handling of non-EU migrant inflows. Foreign Policy Analysis, 9(4), 409-431.

Rijpma, J., Cremona, M. (2007). The extra-Territorialisation of EU migration policies and the rule of law (EUI Working Papers). 
Roccu, R., \& Voltolin, B. (2018). Framing and reframing the EU's engagement with the Mediterranean: Examining the security-stability nexus before and after the Arab uprisings. Mediterranean Politics, 23(1), 1-22. https:/doi.org/10.1080/13629395.2017.1358895.

Roe, E. M. (1991). Development narratives, or making the best of blueprint development. World Development 19(4), pp. 287-300.

Roe, E. (1994). Narrative policy analysis: Theory and practice. Durham: Duke University Press.

Sabatier, P. (2006). Theories of the Policy Process. Boulder. Colorado: Westview Press.

Sabatier, P, \& Jenkins-Smith, H. (Eds.). (1993). Policy Change and Learning: An Advocacy Coalition Approach. Boulder, Colorado: Westview Press.

Sadiki, L. (2004). The search for Arab democracy. Discourses and Counter-Discourses. New York: Columbia University Press.

Saldaña, J. (2013). The coding manual for qualitative researchers. London: Sage Publications.

Seeberg, P. (2015). Regime adaptability and political reconfigurations following the Arab spring: New challenges for EU foreign policies toward the Mediterranean. Middle East Critique, 24(1), 41-53.

Teti, A. (2012). The EU's first response to the 'Arab spring': A critical discourse analysis of the Partnership for Democracy and Shared Prosperity. Mediterranean Politics, 17(3), 266-284.

Under fire at Europe's border. (2005, October 2). The Guardian. Retrieved from https://www.theguardian.com/world/2005/oct/ 02/spain.theobserver.

Melilla: Europe's dirty secret. (2010, April, 17). The Guardian. Retrieved from https://www.theguardian.com/world/2010/apr/17/ melilla-migrants-eu-spain-morocco.

van Hear, N., \& Sørensen-Nyberg, N. (Eds.) (2002). The migration-development nexus. Geneva: United Nations and the International Organization for Migration.

Vega, I. (2017). Empathy, morality, and criminality: The legitimation narratives of U.S. border patrol urgent. Journal of Ethnic Migration Studies, 44(15), 2544-2561.

Wolmer, W. (2006). Understanding policy processes: A review of IDS research on the environment. Brighton: Institute of Development Studies.

Wunderlich, D. (2013). Towards coherence of EU external migration policy? Implementing a complex policy. International Migration, 51(6), 26-40.

Yildiz, A. G. (2016). The European Union's immigration policy: Managing migration in Turkey and Morocco. London: Palgrave Macmillan.

Youngs, R. (2001). Democracy promotion: The case of European Union strategy. Brussels: Centre for European Studies (CEPS).

Zapata-Barrero, R. (2013). The external dimension of migration policy in the Mediterranean region: Premises for the normative debate. Revista del Instituto Español de Estudios Estratégicos, 2, 1-37.

\section{Publisher's Note}

Springer Nature remains neutral with regard to jurisdictional claims in published maps and institutional affiliations.

\section{Submit your manuscript to a SpringerOpen ${ }^{\circ}$ journal and benefit from:}

- Convenient online submission

- Rigorous peer review

- Open access: articles freely available online

- High visibility within the field

- Retaining the copyright to your article

Submit your next manuscript at $\boldsymbol{\Delta}$ springeropen.com 